\title{
La masonería española en Cuba y Marruecos: ideales, imaginarios y utopías coloniales*
}

\author{
por \\ Valeria Aguiar Bobet ${ }^{1}$ \\ Universitat Jaume I de Castellón
}

En este artículo se compara el papel de la masonería española en Cuba y Marruecos a partir de su situación colonial, haciendo hincapié en las variables que subyacen detrás de cada una: cómo legitima o justifica la masonería su actuación en las colonias, si se establece o no como un elemento más de colonización, pero, sobre todo, si termina por configurar un modelo colonial ideal que derivaría en el discurso proyectado en el protectorado español de Marruecos. Con tal fin, la sociología del imaginario nos aportará las bases metodológicas para analizar el discurso masónico y los preceptos que lo configuran, utilizando, como base documental, las fuentes producidas por las instancias masónicas, boletines y periódicos, así como la bibliografía especializada en esta temática.

Palabras Clave: masonería española; Cuba; Marruecos; colonialismo; sociología del imaginario.

Cómo CITAR ESTE ARTículo / CitATion: Aguiar Bobet, Valeria, "La masonería española en Cuba y Marruecos: ideales, imaginarios y utopías coloniales”, Revista de Indias, LXXX/279 (Madrid, 2020): 415-446. https://doi.org/10.3989/revindias.2020.012.

La masonería española se instituyó en todos los territorios coloniales que pertenecieron en algún momento a la metrópoli, pero sus características y desarrollo histórico no siempre fueron las mismas. El tiempo y el espacio en el que la orden se constituyó en cada colonia determinaron sus particularida-

* Este artículo se ha elaborado a partir de una breve comunicación presentada en el V Simposio Internacional de Historia de la Masonería Latinoamericana y Caribeña, La Habana Vieja (Cuba), el 28 de junio de 2017.

1 vaguiar@uji.es, ORCID iD: https://orcid.org/0000-0001-7343-5169 
des y su statu quo. Que la historiografía actual hable de "masonerías" y no de su versión singular "masonería" es, en este sentido, una apreciación acertada y prudente. Sin embargo, las especificidades o generalidades no siempre son una cuestión de blanco o negro; al contrario, las analogías entre hechos o procesos varios, siempre con sus límites metodológicos y conceptuales, permiten al historiador observar paralelos, tendencias o influencias significativas entre ellas. Precisamente, en estas páginas pretendemos valorar y comparar el papel de la masonería española en dos territorios coloniales, Cuba y Marruecos, bastante antagónicos por sus diferencias temporales, espaciales y contextuales: en la Gran Antilla durante el siglo XIX, y en el Magreb a finales de este último siglo y a principios del siguiente, coincidiendo con su implantación y desarrollo. No obstante, la finalidad última de este análisis comparativo será abordar las variables que subyacen detrás de ambas masonerías: de qué manera cada una de ellas legitima o justifica su actuación en cada una de las colonias, si se establecen o no como un elemento más de la colonización $\mathrm{y}$, sobre todo, si terminan por configurar un modelo colonial ideal. Un modelo utópico de masonería, bajo preceptos colonialistas, cosmopolitas y patrióticos que derivaría, a su vez, en las formas y en las características de la última masonería española en un territorio extra-nacional de mayoría musulmana y en nada similar al contexto y a la situación cubana: el protectorado español de Marruecos.

No es nuestro propósito aquí mencionar todas las características y el devenir de la masonería española en Cuba, tampoco en Marruecos, pero sí consideramos necesario establecer algunos elementos identificatorios de las pautas de la colonización masónica en ambos territorios, así como su propia evolución histórica, para poder valorar la configuración narrativa de un posible ideal masónico colonial en el territorio magrebí que habría partido de la experiencia cubana anterior.

\section{LA MASONERÍA AL SERVICIO DEL COLONIALISMO ESPAÑol: DE CUBA A MARRUeCoS}

España ha sido depositaria de una larga y tumultuosa tradición colonial. $\mathrm{Su}$ expansión colonial, junto a la portuguesa, es una de las primeras en desarrollarse en época moderna desde el descubrimiento de América; pero también es una de las primeras en verse afectada por los procesos independentistas de sus colonias americanas en el mismo momento en que otras potencias europeas comenzaban a expandir su influencia por África, Asia y Oceanía. Es más, la pérdida del imperio colonial que España mantenía en el 
continente americano llegó justo en el momento en el que despuntaban nuevas formas de dominio por parte de otros países europeos que desembocaron en el triunfo del imperialismo. En este proceso, los países europeos desplazaron su visión - y sus intereses - a los países musulmanes del Magreb y del Próximo Oriente.

En España el nuevo colonialismo se plasmó en un creciente interés en su vecino marroquí, donde solo había asegurado hasta el siglo XIX sus antiguos fortines y presidios de las plazas fronterizas de Ceuta y Melilla. Hasta este momento, la acción colonial española, tras las grandes e inapelables derrotas de la América continental, se había limitado a mantener los enclaves coloniales preservados tras la quiebra imperial en Cuba, Puerto Rico y Filipinas. Ni en el sudeste asiático ni en la América poscolonial era posible competir con los intereses de Francia, Inglaterra y los Estados Unidos. Era preferible, en consecuencia, consolidar los enclaves bajo control, acabar con la disidencia cubana en las Antillas, expandir la frontera colonial en China, entre otros ${ }^{2}$. Sin poder obviar este nuevo rol de potencia de segundo orden, la actuación española se intensificaría en el Caribe, y solo después de su pérdida se adentraría oficial y taxativamente en África. Y "África” hasta la Primera Guerra Mundial, significaba Marruecos ${ }^{3}$.

En este contexto, Cuba fue una de las últimas colonias de Ultramar de ese gran Imperio donde no se ponía el sol y, Marruecos, la nueva ocupación durante el periodo decimonónico imperialista y colonialista de Europa. Los cambios políticos y económicos que esto supondría a lo largo del siglo XIX en España explican su repliegue de la esfera internacional (que ha sido utilizado para teorizar el paso del "imperio a nación" o del "imperio a Ultramar"4). Así, el punto de mira de los sectores colonialistas españoles se fue trasladando desde el marco caribeño-filipino hacia el occidente magrebí, reorientación que se intensificó tras la pérdida de Cuba, Filipinas y Puerto Rico en 1898. Se trató de un proceso largo que se incrementaría a partir de la década de los 80 del siglo XIX con una intervención más activa en Marruecos para aumen-

2 Martín Corrales, 2002b: 169.

3 Sá, 2015.

4 Francisco Javier Martínez Antonio establece que, al menos, durante el periodo isabelino es más correcto hablar de una España peninsular y una España ultramarina o España-Cuba más que de un imperio colonial español. El conjunto de ambas expresiones reflejaría mejor la débil realidad imperial hispana y la particular relación hispano-cubana que la dicotomía metrópoli-colonia. Además, esta terminología dupla expresa mejor la singularidad de la España isabelina, su carácter intermedio entre las grandes potencias mundiales y aquellas formaciones sociales colonizadas o en vías de colonización en Asia y África. Martínez Antonio, 2011: 26-27. 
tar su influencia. Fue el periodo conocido como "penetración pacífica", en el que cabe contextualizar la revitalización del arabismo, el surgimiento del africanismo, la creación en 1876 de la Sociedad Geográfica de Madrid (después Real Sociedad Geográfica) entre otras expediciones y viajes. Marruecos, para la España de los siglos XIX y XX, sería el territorio privilegiado donde ejercer la acción colonizadora, donde definir sus pretensiones y su potencial político y militar. Era el espacio idóneo donde el espejismo de una colonización de nuevo tipo podía concretarse, sobre todo después de la derrota del 98 que pondría fin a la influencia y control antillano

En definitiva, la única compensación a las pérdidas de Cuba, Puerto Rico y Filipinas fue el establecimiento del protectorado de Marruecos (desde 1912, aunque solo fue efectivo a partir de 1927 tras las guerras sangrientas del Rif), el control de una estrecha franja en la costa occidental del Sáhara (efectivo desde 1934) y el dominio de los territorios de Fernando Poo y Río Muni, en el golfo de Guinea (ocupados a partir de 1874). El resultado final, guiado también por la presión europea, en concreto por los intereses británicos y franceses, selló la pérdida de la independencia de Marruecos. La modalidad del reparto se solucionó entre la conferencia de Algeciras en 1906 y la firma del tratado del protectorado franco-marroquí al que después se adhirió España en 1912.

El papel de la masonería española en ambos contextos coloniales, Cuba y Marruecos, a lo largo del siglo XIX y las primeras décadas del XX, pululará en esta misma diacronía y sincronía. Producto y consecuencia de la acción colonial, la ocupación y desocupación masónica de los dos territorios se diferencian y se interrelacionan de igual modo, por lo que, para una mejor exposición del discurso, abordaremos la iniciación y situación de la masonería en cada uno de ellos.

\section{LA MASONERÍA ESPAÑOLA EN CUBA ${ }^{6}$}

Los primeros talleres masónicos españoles instaurados en Cuba coinciden en el tiempo, aproximadamente, con los primeros implantados en España. Los

5 Martín Corrales, 2002b: 169.

${ }^{6}$ El estudio de Castellano es exclusivo de la actuación masónica metropolitana en Cuba, Castellano Gil, 1996. No obstante, existen otros estudios, en manos de la historiografía cubana, española y francesa, que versan sobre la masonería cubana o la masonería en Cuba. Véase, por ejemplo, el resumen realizado para las masonerías en Cuba en el siglo XIX por Torres Cuevas, 2017. 
inicios de la masonería en ambos casos se sitúan en los primeros años del siglo XIX ${ }^{7}$. A diferencia de otros países europeos, en España la institución de la masonería fue un hecho tardío, por lo que "los primeros pasos" de la orden en la perla de las Antillas estuvieron bajo tutela inglesa, francesa y norteamericana $^{8}$. Las diversas logias constituidas, adscritas a diferentes obediencias, desarrollaron sus actividades sin grandes problemas hasta mediados de los años 20, momento en el que sufre una paralización que duraría hasta 1859 . El origen de este resquebrajamiento fue, en gran medida, por el restablecimiento absolutista, los problemas derivados de la emancipación de la América continental española y el fomento y creación de una serie de sociedades secretas que tenían como fin la independencia de la isla ${ }^{9}$.

En paralelo, la implantación sistemática de la masonería en Cuba se produce a partir de finales de la década de los $50^{10}$, en unos instantes en que la masonería de la España peninsular estaba desorganizada y casi había desaparecido. Y aunque existió un intento de institución de logias españolas en 1821 en el que el Gran Oriente Francés cedió los derechos al Gran Oriente Nacional de España, terminó fracasando. Más que por el poco interés prestado por este último, los conflictos y las divisiones internas de la masonería peninsular derivaron en la independencia de las logias que lo constituían y en la configuración de una obediencia propia ${ }^{11}$. La consecuencia directa de ello fue la consolidación de una masonería cubana independiente de la metrópoli, una masonería pre-española compuesta por españoles, cubanos per se, otros europeos y norteamericanos.

No será hasta mediados de la década de los setenta del ochocientos cuando aparezcan los primeros organismos masónicos dependientes de orientes españoles. A partir de la revolución de 1868, y de la subsiguiente constitución, se reconocerá la libertad de reunión y de asociación en España posibilitando el renacimiento de la masonería española en $\mathrm{Cuba}^{12}$. En concreto, en $1875 \mathrm{se}$ integraron los primeros talleres al Gran Oriente De España. Solo entonces las principales obediencias españolas tuvieron representación en la Isla y se desarrollaron en función de su propia dinámica interna. De este modo, la penetración masónica española oficial, es decir, su colonización masónica,

7 Existió una masonería gibraltareña anterior asociada a las obediencias británicas, pero la masonería institucionalizada comenzaría en el siglo XIX.

8 Véase, entre otros, Soucy, 2006; Torres Cuevas, 2013; Saunier, 2017.

9 Torres Cuevas, 2017: 58-64.

10 Paz, 1979: 534.

11 Byrne, 1913: 4; Castellano Gil, 1996: 52.

12 Ibidem: 77. 
se iniciará después de varias décadas de actividades e historia de la orden en la isla. No obstante, tal independencia suponía la existencia de un temor latente por la relación entre las ideas independentistas de algunos talleres cubanos y de la masonería, que conllevaría a una fuerte antimasonería y a la prohibición y persecución de esta por parte de España. En otras palabras, la preexistente situación masónica cubana supondría un reto para la expansión española en un contexto colonial bastante largo de colonización hispana en Cuba que se resumiría en una dura lucha y rivalidad entre las obediencias insulares y las españolas por la hegemonía jurisdiccional del territorio.

Sin ser nuestro objetivo abordar las vicisitudes en la historia de la masonería en la isla, de forma general, una vez implantada, hubo diferentes obediencias peninsulares que actuaron en la isla en diferentes cómputos temporales: el Gran Oriente de España, El Gran Oriente Nacional de España, el Gran Oriente Español, el Gran Consejo General Ibérico y la Gran Logia Simbólica Española del Rito Antiguo y Primitivo Oriental de Memphis y Mizraim. La gran heterogeneidad es prueba suficiente de las pugnas, enfrentamientos y fracturación de la masonería española, un elemento clave que contrasta con la mayor unidad de la cubana-criolla y que explica, entre otras cosas, su debilidad en el control masónico de las colonias ${ }^{13}$.

Respecto a su actuación, destacamos dos cuestiones importantes. Primero, el Gran Oriente Nacional de España, una de las obediencias españolas con más fuerza en Cuba en la década de los ochenta, a pesar de las crisis internas, escisiones y divisiones anteriores, comienza a generalizar una idea entre la masonería de la isla: la unificación o unidad masónica. La iniciativa, que surgió de las logias de obediencia cubana, tuvo como resultado la fusión entre el Gran Oriente de Colón y la Gran Logia de la Isla de Cuba que ya estaba bajo los auspicios del Gran Oriente Nacional; pero también surgiría de forma paralela en la masonería peninsular, sobre todo para hacer frente a una realidad dominada por las divisiones y las disidencias. La unidad se convertía, así, en un elemento de lucha frente a la Gran Logia Unida de Colón, propiamente antillana y con tendencia autonomista ${ }^{14}$. Sin embargo detrás de la idea de convergencia, como se reflejará con los años en los diversos discursos de las logias de obediencia hispana, subyacía otro problema de fondo, el más representativo de la actuación y significación colonial de la masonería española en Cuba: trabajar por mantener la hegemonía colonial hispana en la isla.

13 También la masonería cubana tuvo sus propias vicisitudes internas. Sin embargo, la actuación española siempre estuvo condicionada por la desorganización masónica de la metrópoli. Torres Cuevas, 2017: 64-75.

14 Castellano Gil, 1996: 97-98 
Y esto significaba no perder Cuba, asegurar su control colonial, empezando por la masonería para después ampliarse al resto de la política española. Y el hecho de que las obediencias cubanas mencionadas se anexionaran a las peninsulares y apoyaran la unidad solo demuestra, entre otras cosas, que algunos de sus componentes eran partidarios de la continuación de la ocupación española. Torres Cuevas reafirma en sus obras constantemente que «ni todos los autonomistas eran masones, ni todos los masones autonomistas» ${ }^{15}$.

En segundo lugar, la política del Gran Oriente de España, ya a finales del siglo XIX, bajo su Gran Maestre Miguel Morayta, resumiría otra de las cuestiones esenciales para comprender la actuación masónica peninsular de la isla: el asimilismo ${ }^{16}$. El organismo solicitaba que se aplicara en Cuba la constitución de 1876, la Ley de Prensa y de Asociación, manifestando su adhesión a la concepción de integridad del Estado. Además, promovía y fomentaba la íntima unión de los pueblos latinoamericanos, asentándose sobre principios patrióticos, pues pretendía contribuir a crear «una patria poderosa, feliz, respetada e influyente en los destinos [...], una gran nacionalidad, por la Confederación política de los numerosos Estados americanos descendientes de los descubridores y pobladores hispano-portugueses, con la noble Portugal y nuestra generosa España» ${ }^{17}$. Además, se encaminaba, por un lado, a desvirtuar los efectos de la política absorbente de los Estados Unidos y, por otro, se defendía la idea de que el porvenir de España seguía estando en América con la apertura de sus mercados. De este modo, podría decirse que la colonización masónica en Cuba buscaba afianzar la hegemonía española en la isla en detrimento de las otras obediencias - extranacionales o propiamente criollasque actuaban en ella. Y esto, en perjuicio de aquellos sectores masónicos y no masónicos que, especialmente, abogaban por la emancipación de esta colonia de la metrópoli, aunque tuviese normalmente un carácter individual y nunca como propósito marcado por la orden ${ }^{18}$. En definitiva, tenían la intención de mejorar la actuación política española de la isla, otorgándole los mismos privilegios de la Península y así, de algún modo, reconciliar la pésima actuación de España concedida en sus anteriores colonias americanas. Todo ello, por supuesto, para incentivar la ya casi perdida grandeza imperial de la nación.

15 Torres Cuevas, 2017: 69.

$16 \mathrm{Paz}, 2006 \mathrm{~b}$.

17 Carta del Supremo Consejo del $33^{\circ}$ de Cuba y Puerto Rico a Miguel Morayta, 31 de agosto de1898. Centro Documental de la Memoria Histórica (CDMH), Sección (S) Especial (E) Masonería A, legajo 379 exp. 17.

18 Castellano Gil, 1996: 284. 
De este modo, a pesar de los conflictos respecto al nacionalismo e independentismo cubano de estas décadas, la presencia masónica española en la Gran Antilla fue bastante considerable y tumultuosa. Aun así, se llegaron a establecer más de 200 talleres con 5745 masones de unos 8181 que se calculan de forma aproximada para todo el territorio español, un $70 \%$ del total ${ }^{19}$. Ferrer Benimeli y Castellano Gil coinciden en que la mayor concentración de talleres residió en La Habana y en otras provincias occidentales. Existiría, por tanto, un acusado contraste Oriente-Occidente ${ }^{20}$, una fuerte concentración urbana y un evidente distanciamiento de los centros controlados por los insurrectos, situados precisamente, en la zona oriental. Presentaría, junto a ello, un carácter mesocrático y urbano pues en gran medida estaría integrada por comerciantes, industriales, empleados $\left(50 \%{ }^{21}\right)$ y otras profesiones liberales, propietarios y hacendados $(8 \%)$, y una notoria participación del componente militar (4\%), a diferencia de los masones integrantes de la Gran Logia Unida de la Isla de Cuba con un índice menor $(1 \%)^{22}$.

Respecto a la nacionalidad de los miembros de los talleres, los resultados obtenidos por los investigadores antes nombrados determinan la importancia numérica de los españoles nacidos fuera de la isla caribeña, seguidos de otra destacada cifra de criollos, así como un porcentaje elevado de chinos en relación con otros países. De este modo, las obediencias españolas estarían compuestas esencialmente por españoles nacidos fuera de la isla y, la obediencia cubana integrada, fundamentalmente, por criollos. Por tanto, tal y como apunta Castellano Gil, «estas agrupaciones venían a representar intereses contrarios y, muy especialmente, simbolizados en el sentimiento respecto a la ideología política: la lucha entre el independentismo y el integrismo». Eso sí, sin que esto haya significado un elemento discriminatorio, sino más bien al contrario, se produjo una convivencia pacífica entre criollos y españoles en las obediencias hispanas y en la Gran Logia Unida de Colón. Es más, en algunas logias el número de españoles es superior al de cubanos y en otras, más o menos equilibrado ${ }^{23}$.

Por otro lado, la composición "racial" de las logias españolas que destacamos aquí, al ser un elemento fundamental en la analogía con las logias hispano-marroquíes, presenta valoraciones opuestas a esta comunión masóni-

19 Ferrer Benimeli, 2000.

20 Castellano Gil, 1996: 192.

21 Los porcentajes han sido establecidos en función de la documentación encontrada, un $72 \%$ del total de los miembros. Ibidem: 322.

22 Ibidem: 326.

23 Ibidem: 330-333. 
ca entre criollos y españoles. La masonería, como defensora de los principios de igualdad y libertad entre hombres, no se opuso, salvo en algunos casos, al sistema esclavista ${ }^{24}$. Es más, muchos de sus integrantes pertenecieron a la burguesía que lo avalaba. No será hasta finales de la centuria cuando la masonería hispana en la isla caribeña apoyaría la abolición del Patronato en 1886, presentando este logro como un triunfo obtenido por el esfuerzo de los jóvenes diputados cubanos pertenecientes a la Gran Logia Unida de Colón e Isla de $\mathrm{Cuba}^{25}$. De hecho, estas primeras manifestaciones de la institución masónica cubana respecto al esclavismo, lo consideraban como «un baldón para la Patria» y exhortaban el deber de la masonería hacia los desheredados de la fortuna, «amparándolos y protegiéndolos contra la ignorancia y la ambición que los explota» ${ }^{26}$. Sin embargo, una cuestión era el problema de la esclavitud y la tardía respuesta de la masonería cubana, y otra muy distinta la discriminación racial en el seno de la institución. El periódico oficial de la Gran Logia de la Isla de Cuba establecía en 1879:

Jamás. La Masonería, en los países donde, como en Cuba (único ya del globo) hay raza de parias, la Masonería tiene más santa y más noble misión que en otras partes; tiene la misión de ir colmando poco a poco el abismo ahondado entre una y otra raza por la maldad y la avaricia; sus medios son los mansos y pacíficos de la persuasión, de la caridad, y más que nada del fraternal consorcio de ambas razas en los Templos, bajo el pie de la igualdad más estricta ${ }^{27}$.

Aunque Castellano Gil en su estudio no menciona la actitud tomada por las logias españolas en concreto, sí establece que diversas fueron las discusiones sobre la integración de individuos negros en los talleres cubanos del siglo XIX, pero la mayoría de ocasiones el voto siempre fue adverso a su admisión por las circunstancias físicas en medio de las teorías poligenistas y también de los intereses económicos de algunos de sus miembros, al igual que en el caso de la masonería francesa antillana ${ }^{28}$. Al considerar a la orden como una sociedad caracterizada por la igualdad entre sus miembros, este principio se perdería desde el mismo instante en que se admitieran candidatos de «una raza civilmente inferior, exponiéndolos a desaires y menosprecios

${ }^{24}$ El "miedo al negro" por los sucesos acaecidos en Haití estuvo a la orden del día, aunque menguaría en la segunda mitad del siglo XIX.

25 La Verdad, II/ 20 (Cuba, 20 de septiembre de 1886): 2.

${ }_{26}$ Boletín oficial del Gran Oriente de Colón para las Indias Occidentales, III/26 (Cuba, 1 de febrero de 1877): 90.

27 Periódico Oficial de la Gran Logia de la Isla de Cuba, III/ 9 (Cuba, 1 de mayo de 1879): 143-144.

28 Saunier, 2017. 
frecuentes en la logia» ${ }^{29}$. Ante todo, la masonería debía ser una organización entre pares y esto divergía cuando se trataba de la población negra, al igual que lo sería de la musulmana ${ }^{30}$.Tampoco debemos olvidar que el rechazo a la supresión del sistema esclavista era romper con los intereses de la aristocracia de la Isla, a la que pertenecían la mayoría de los masones y, por otro, que "el miedo al negro" era una constante después de los sucesos de Haitíi ${ }^{31}$. A pesar de ello, hay varios indicios que hablan de cierta participación, aunque minoritaria, de negros y mestizos en algunos talleres. El decreto de 9 de octubre de 1879 hacía referencia a que en el momento en que se llevó a cabo la promulgación de los Estatutos de la Gran Logia no tenían acceso a la institución los hombres negros. Por esta causa, se ordenaba que, a partir de esos momentos, se debía recoger en las peticiones de admisión de candidatos, además de los aspectos detallados en el artículo $9^{\circ}$ del estatuto, la raza del candidato y su «condición de ingenuo en caso de ser negro»" ${ }^{32}$. Como veremos más adelante, estas sentencias volverían a replantearse, en un tono algo más integrador y conciliador, con los "indígenas" del Magreb, es decir, con los marroquíes árabes y bereberes de religión musulmana.

No obstante, sin menosprecio de esta quimérica integración de la población negra-esclava en la masonería, el principal problema de las logias españolas en la Gran Antilla derivó y se centró, especialmente, en dos cuestiones: la hegemonía de las obediencias hispanas frente a las cubanas y su rechazo al independentismo de la isla. Asimilismo y amor a la patria parecen ser los caminos adoptados por los talleres que las circunscribieron. Así, con tan solo 40 años de implantación de la masonería española en Cuba, en pugna constante por su legitimidad y autoridad, terminaría con la guerra de independencia en 1898 . Y con ello, el pensamiento filosófico-pacifista que había propugnado la masonería hispánica frente a los conflictos internacionales se traduciría en una conducta totalmente opuesta para resolver el conflicto armado del Caribe. Es más, la empresa bélica fue considerada, por todas las obediencias peninsulares, como un gran dogma masónico definido por la defensa de la integridad del territorio nacional y que, por tanto, justificaba la intervención militar:

Somos como masones enemigos decididos de la guerra, pero antes que masones somos españoles y, como españoles amantes entusiastas de nuestra querida

29 Periódico Oficial de la Gran Logia de la Isla de Cuba, III/ 9 (Cuba, 1 de mayo de 1879): 143-144.

30 Aguiar Bobet, 2017-2018.

31 Hernández González, 2012: 167 y 207; Saunier, 1999.

32 Periódico Oficial de la Gran Logia de la Isla de Cuba, III/ 9 (Cuba, 1 de noviembre de 1879): 325 . 
patria, aceptamos y proclamamos la guerra con todas sus funestas y fatales consecuencias que no desconocemos ${ }^{33}$.

Retomaremos esta idea más adelante. Ahora, no obstante, es preciso abordar, de acuerdo con el orden indicado, la actuación masónica española en Marruecos estableciendo las analogías precisas con su homónima en Cuba.

\section{La MASONERÍA ESPAÑOLA EN MARRUecos}

Si bien la masonería española en Cuba se institucionalizó a partir de la década de los 60, en Marruecos no se iniciará este proceso hasta una década más tarde. Y aunque existiesen algunas logias precedentes en Ceuta, Melilla y Tánger desde 1821 y $1860^{34}$, correspondientes a aquellos españoles, especialmente militares, que empezaban a ocupar las plazas más importantes del Magreb, también es cierto que la presencia española en Marruecos difiere en rotundidad de la residente en Cuba: con varios siglos de colonización española en su historia, la isla antillana conocerá primero el colonialismo hispano y después la expansión masónica, aunque primero se estableciera la extranjera y luego la propia. En Marruecos, la institución de talleres masónicos en manos de españoles precederá a la colonización oficial de la metrópoli. Y, además, la constitución de estas logias coincidirá en el tiempo con otras francesas e inglesas en aquellas ciudades de mayor importancia portuaria y comercial, especialmente en Tánger, que parecía tener las mejores condiciones para servir de centro de implantación — y difusión - en Marruecos de la francmasonería ${ }^{35}$.

Tánger era la ciudad de residencia del sultán ante las potencias extranjeras y la que acogía tradicionalmente al cuerpo diplomático europeo acreditado.

33 Boletín de Procedimientos. Órgano oficial del Soberano Consejo General Ibérico X/4 (Madrid, 27 de abril de 1898): 1-2.

34 Según establece este autor, las primeras logias francófonas en el país, pertenecientes a la Gran Logia De Francia se establecen en Tánger en 1867 donde se encuentran en presencia de logias españolas, interesadas también en la penetración europea en el Mediterráneo, como también los masones de las logias inglesas de Gibraltar. Odo, 2001: 52. No obstante, la primera logia documentada en el Imperio marroquí será Luz de Marruecos en Tetuán en 1881 del Gran Oriente Nacional de España (GODE). En Melilla, los primeros testimonios de trabajo de talleres fueron Amor y Excelsior en 1874. Moga Romero, 2005, vol. I: 88. En Ceuta serán las logias, Africana no. 112 en 1876 del GODE, aunque nuevos aportes indican que ya hubo un taller en 1821, Antorcha de Israel. Moga Romero, 1987.

35 Moga Romero, 2005: 73. 
Quedaba sometida a un fuero especial de capitulaciones, dispensado por los cónsules de las diversas potencias establecidas, que escapaba a la jurisdicción marroquí ${ }^{36}$. Era una ciudad abierta y acostumbrada al trato con los extranjeros que utilizaban asiduamente los servicios de su puerto y de la aduana. Una ciudad en la que el término de masonería no era desconocido. De hecho, tal y como señala Georges Odo en sus estudios de la masonería colonial francesa, serán los talleres españoles los más activos en esta ciudad en relación, especialmente, a los del país vecino ${ }^{37}$. Una particularidad diferencial con respecto a las logias de obediencia extranjera en Cuba que protagonizarían los primeros esfuerzos masónicos de la isla.

No es de extrañar, en este sentido, que desde 1880 se instituyan diferentes logias en las plazas de soberanía y Tánger de forma más sistemática debido, precisamente, a la importancia, según indica el Boletín del Gran Oriente Nacional de España «que está tomando Marruecos para España y el gran número de durmientes masones en este territorio» ${ }^{38} \tan$ solo unos años después de las establecidas en Cuba. Ni tampoco que se configure en 1890 el Gran Oriente de Marruecos ${ }^{39}$ en Tánger, con autonomía e independencia propia, geográfica y jurisdiccionalmente. En este caso, al igual que en los primeros inicios de la masonería en Cuba, las adversidades sufridas por las obediencias españolas, en pugna constante por su hegemonía en el territorio nacional, conllevarían una iniciativa convergente, unitaria y mejor organizada de las logias norteafricanas que de forma paralela a la metrópoli y, en ningún caso, asociada o auspiciada por las obediencias peninsulares. Es más, uno de los objetivos autoimpuestos por este Gran Oriente, será, precisamente, trabajar por la regeneración de la masonería peninsular ${ }^{40}$. La unión masónica en el Imperio de Marruecos establecía, en este sentido, que «todos trabajamos ya bajo los auspicios de una autoridad masónica de origen africano [...]. Como buenos ciudadanos, somos amantes de nuestra patria [...] [que] vive en las tinieblas y por lo tanto pobre y miserable» ${ }^{41}$.

36 López García, 2012.

37 Odo, 2001: 60.

38 Carta de la logia Unión Ibérica-Africana al Gran Oriente Nacional de España, Tánger-Madrid 1888, CDMH, SE Masonería A, legajo 771.

39 La documentación abarca de 1890 a 1892. La constitución del Supremo Consejo del Grado 33 fue el 30 de mayo de 1890 y la asamblea de constitución el 26 de abril de 1890. Se publica oficialmente en La unión Masónica en el Imperio de Marruecos no. extraordinario, (Tánger, junio 1890): 3-4.

40 Moga Romero, 2005: 74-75.

${ }^{41}$ La Unión Masónica en el Imperio de Marruecos, 3 (Tánger,1 de marzo de 1890): $1-2$. 
El Gran Oriente de Marruecos se fundará por obra del comandante Julio Cervera, justo un año después de la fundación del Gran Oriente Español, y precisamente con estos objetivos: "reunificar" a los masones de Marruecos y "regenerar" a la masonería española. La referencia a la "unificación" revela la existencia de un cierto número de logias que funcionaban - en ocasiones durante breves periodos de tiempo- sin estructurarse en obediencias. Las logias adscritas pertenecían a varias potencias masónicas de distintos países europeos (La Saeida, Abd-El-Aziz, Luz de Marruecos, Luz de Rabat, Fez, entre otras). A su asamblea constitutiva asistieron diputaciones de masones de logias americanas, inglesas, españolas y francesas. En el sello que se diseñó para sus documentos, además de la imaginería típicamente masónica, se incluían también la media luna y el lema en árabe "Gran Oriente de Marruecos". Es más, de las seis personas que formaron el primer Supremo Consejo, todos ellos de grado $33^{\circ}$, dos tienen nombre árabe, uno de ellos era el ayudante de campo del Sultán ${ }^{42}$.

No obstante, a partir de septiembre de 1891 se reanudan las relaciones de la potencia surgida con el Gran Oriente Español, sobre todo para paliar las persecuciones que estaban sufriendo por parte del sultán de Marruecos, nada satisfecho con la actuación de Julio Cervera y de la nueva Legación española en Tánger ${ }^{43}$. Relaciones que además derivaron en la petición de integración en la obediencia española citada ${ }^{44}$. Esto significaría, por un lado, la disolución del Gran Oriente de Marruecos, y a su vez, la fusión de las logias adscritas y de los "masones libres" al Gran Oriente Español45. Con esta decisión, el Gran Maestre del Gran Oriente Español, Miguel Morayta, proclamaría «la ocupación masónica del territorio marroquí» pasando así a denominarse Gran Oriente Español para España, sus provincias de Ultramar y Marruecos. ${ }^{46}$ La masonería quedaría, desde entonces, unificada completamente a la española y, cómo no, al servicio del colonialismo español.

En todo caso, al "fracaso" del Gran Oriente de Marruecos no fueron ajenos los intereses coloniales hispanos que, entre otras cuestiones, no podían permitir que el territorio cherifiano tuviese una obediencia masónica independiente cuando lo que se estaba forjando era su ocupación. Igualmente, puede

42 Sampedro, 2015: 327.

43 Ibidem: 173-175.

44 Carta, 5 de noviembre de 1981. CDMH, SE Masonería A, legajo 771. exp. 8.

45 Anuario del Gran Oriente Español (1895): 97. Entre 1890-1899, esta obediencia incluiría seis logias del territorio marroquí: cuatro logias en Tánger y las demás en Alcazarquivir, Fez, Rabat y Tetuán.

46 Moga Romero, 2005: 85-88. 
intuirse el papel que pudo jugar, en esos momentos, el Gran Oriente Español en apoyo de las expectativas de la política exterior española respecto al Imperio cherifiano. La llegada a España de una "Embajada masónica marroquí", invitada por dicha obediencia y anunciada desde inicios de 1892, pareció contribuir a crear la idea de que dicha embajada traía a España una misión más oculta que el exclusivo abrazo fraternal ${ }^{47}$. De hecho, fue denunciada por otros masones hispano-marroquíes quienes rápidamente replicaron que no representaba a la masonería del territorio y que tal proceder debía constar en acta. Más que otra cosa, lo que subyacía detrás de estas consideraciones era el intento de salvaguardar el predominio de las obediencias españolas peninsulares, a la vez que impedir la constitución de una institución masónica independiente con sede en el territorio marroquí: «no era cuestión propiciar que el emir de los Creyentes pudiera también ser algún día el Gran Maestre del Gran Oriente de Marruecos» ${ }^{48}$.

Sea como fuere, a partir de esta oficialización de la colonización masónica española podemos distinguir varias fases en su trayectoria histórica; fases que difieren, por su complejidad, del esquema prototípico de implantación, expansión y consolidación ${ }^{49}$. La primera de ellas, se instituiría precisamente en torno a las primeras logias de la ciudad tangerina, la implantación del Gran Oriente de Marruecos y los talleres que continuaron después de su disolución, es decir, entre 1870 y 1899. En una segunda etapa, las logias que perpetuaron sus trabajos con mayor o menor constancia durante y después la guerra de la independencia cubana y de la desestructuración masónica general que desencadenó, se reactivarían con mayor vehemencia a partir de 1900 pero, sobre todo, de 1905. Además, la promulgación del tratado de Algeciras franco-español (1906) y la instauración del protectorado oficial (1912) incrementarían la constitución de nuevos talleres españoles bajo la hegemonía exclusiva del Gran Oriente Español, en Tánger y en aquellos enclaves que comenzaban a destacar por su importancia militar, comercial o portuaria en la zona de influencia francesa (Casablanca, Fez, Rabat y Marrakech). Este nuevo impulso, que llegará hasta finales de los años veinte, abrirá una tercera etapa, donde se conformará otra gran logia en Tánger, esta vez con carácter federativo, auspiciada por el GOE, La Gran Logia Regional de Marruecos (GLRM) y, además, entrará en el juego colonial la Gran Logia de España, fundando los primeros talleres (mejor consolidados y duraderos) en el protectorado español, sobre todo en su

$47 \mathrm{CDMH}, \mathrm{SE}$ Masonería A, legajo 771 exp. 8.

48 Moga Romero, 2005: 88.

49 Con este esquema delimita G. Odo la actuación masónica francesa en África. Odo, 2001: 59. 
puerto comercial-principal, Larache, y en Alcazarquivir. No obstante, la corta e inestable duración de la GLRM ${ }^{50}$ y el cierre de las logias de la GLE, dejaría entrever la difícil situación de los españoles en África durante estos años, tanto por la inestabilidad del territorio rifeño - las conocidas guerras del Rif (1921-1927) - , como por las propias persecuciones hacía los miembros de la institución bajo la dictadura de Primero de Rivera (1923-1927). En cualquier caso, este tercer periodo corresponde a la ocupación sistemática y oficial de la colonización masónica española en su zona de influencia, cuyas acciones y trabajos abordaron siempre la conciliación y tolerancia entre las tres culturas que nutrían la población del Magreb (cristianos, judíos y musulmanes), la promulgación de una educación laica para el territorio entre otras cuestiones que resumían, en definitiva, el "ideal" o la "misión" impuesta por la masonería ${ }^{51}$ : "civilizar" Marruecos, como veremos más adelante.

La última fase de la historia masónica española en el Norte de África comienza en los años treinta y se cierra, como en el caso cubano, con una guerra. Abarca el periodo de la Segunda República y el inicio de la guerra civil española. No obstante, esta guerra será fratricida y en ningún caso apoyada o legitimada por ninguna institución masónica. Más, al contrario, serán los miembros de la orden quienes estarán fuertemente perseguidos y represaliados por los sublevados en su "Glorioso Movimiento Nacional". La característica principal, en todo caso, será que en esta última etapa la historia de la masonería hispano-magrebí llegará a su máximo exponencial -22 talleres simbólicos y 3 filosóficos en las tres zonas en las que se dividía el Imperio, con casi novecientos miembros-y, además, la actividad mayoritaria se centrará, por primera vez, en la zona de influencia hispana. Y es que a partir de la proclamación de la República y su significación ideológico-liberal se fundaron nuevos talleres más proactivos en las distintas plazas de la colonia (Tetuán, Larache, Alcazarquivir, Chauen, Villa Alhucemas), junto con Casablanca y Fez de la zona francesa, y Tánger como territorio con estatuto internacional, las tres ciudades con mayor importancia masónica en los periodos precedentes. En esta ocasión, Tetuán, la capital del protectorado, será el nuevo centro neurálgico de sesta masonería, convirtiéndose en la sede de la nueva Gran Logia de Marruecos en noviembre de 1932 bajo los auspicios del Gran Oriente Español. En paralelo, la Gran Logia Española tendrá una crucial representatividad en diferentes zonas del territorio, aunque con una cuantía menor de talleres y de integrantes. Pero, en conjunto, las logias masónico-re-

\footnotetext{
50 Abarca 1923-1927. CDMH, SE. Masonería A, legajo 769.

51 Ferrer Benimeli, 1992; Paz, 2009.
} 
publicanas serán las más organizadas en cuanto a estructura y vida interna, además de ser las más prolíficas en cuanto a trabajos realizados y a la acción masónica en la colonia en pro de su alta misión "civilizatoria" 52.

A grandes rasgos, los resultados obtenidos en cuanto a su composición socio-profesional determinan que la mayoría de los talleres estaban compuestos de personal civil que ocupaba las filas de la administración del protectorado, comerciantes, industriales y un porcentaje significativo de la población nativa compuesta por judíos sefardíes y musulmanes. En las tres primeras etapas, el número de judíos fue superior en algunos talleres, especialmente en Tánger, Casablanca y Fez (con cifras de más del 50\% y con ciertas divisiones intermasónicas que respondían a logias más "cristianas" y otras "más judías"). El número de musulmanes, por su parte, fue mucho menor, apenas representativo, constando dos o tres en algunas logias, especialmente miembros de la élite colaboracionista. En la época republicana, al contrario, la tendencia se modificaría hacia una mayor "españolización" de los componentes pero, a su vez, incluyendo un repunte notable de iniciados musulmanes $(24 \%$ de judíos, $3,2 \%$ de musulmanes y $72 \%$ de europeos en general) pero también una caída considerable de judíos en las filas del Arte Real ${ }^{53}$. Respecto al número de militares, cabe especificar que desde un principio compusieron los talleres masónicos por razones de estabilización de la colonia. De hecho, el Gran Oriente de Marruecos fue fundado directamente por algunos integrantes del ejército. No obstante, tal y como indican otros estudios realizados por Manuel de Paz y Moga Romero ${ }^{54}$, este porcentaje fue decreciendo a medida que se consolidaba la ocupación española, por lo que su presencia no sería tan relevante (con la excepción de momentos puntuales, como sucedería en la logia Tetuán no 64 de la GLE en 1929 y 193055).

Por otra parte, no se puede olvidar que la situación de la masonería española gozaba de una atípica excepcionalidad en el Norte de África, puesto que,

52 Aguiar Bobet, 2019a: 34-65; Aguiar Bobet, 2017a: 494-496.

53 Aguiar Bobet, 2019b: 195-197; Aguiar Bobet, 2017-2018: 89-90.

54 Moga Romero y Perpén Rueda, 1990; Paz, 2006a: 273-349.

55 Tan solo en 1929 y 1930 los militares destacarán en las logias hispano-marroquíes, en concreto, en la logia Tetuán $n^{\circ} 64$ de la Gran Logia Española. Las causas de la configuración del taller y el protagonismo de la milicia en ella fueron el final de las guerras rifeñas, el retorno de los militares a la capital, Tetuán, donde se instituiría, además de percibir la orden como un instrumento pseudo-político para promocionar los ideales liberales y republicanos. También unos años antes había existido un triángulo formado por el elemento castrense denominado Allah en Villa Cisneros, pero no llegaría a consolidarse. Durante la República el número de componentes de este grupo seguirá siendo importante, pero en ningún caso mayoritario. Véase, Paz, 2006a: 274-280. 
a diferencia de las iniciativas de los masones cubanos, los componentes no marroquíes activos de los talleres siempre tendrían la nacionalidad española, antes y durante el proceso colonial. Esto es obvio, no se puede hablar de criollos ni de españoles marroquíes en el contexto colonialista europeo, aunque sí podemos destacar los intereses de muchos protegidos sefardíes y andalusíes por conseguir la naturalización y nacionalización española, un proceso que, no sin altibajos, solo consiguieron algunos pocos ${ }^{56}$. Tampoco puede hablarse de una composición racial en cuanto a individuos negros. En otro sentido, será la pluralidad étnico-cultural y religiosa del territorio cherifiano, la esencia y la particularidad de estas logias. Es decir, serán los componentes marroquíes, tanto judíos, principalmente sefardíes, como musulmanes árabes y bereberes - especialmente los dos últimos - los que denotarán un sentido "misionero", en términos de Georges Odo ${ }^{57}$, a la masonería en Marruecos, quizás solo comparable con la aceptación o no de hombres negros en las logias cubanas. La colonización masónica española del Magreb desde sus inicios, se conformaría en torno a las mismas bases establecidas por el colonialismo del periodo: "civilizar" es "colonizar", diría Martínez Barrios en su célebre discurso durante su visita de inspección a las logias norteafricanas en $1927^{58}$. La más básica de todas las propuestas, acciones y misiones en el Magreb, y por ello, la más importante para cumplir con su misión colonialista y civilizadora fue, por tanto, la integración de "indígenas", que eran la mayoría "incivilizada" de este territorio:

La GLRM debe trabajar intensivamente porque nuestro postulado arraigue profundamente en el elemento musulmán indicando a todos los talleres de su jurisprudencia la conveniencia de dedicar su especial atención a los indígenas [...] con lo cual llevaremos a feliz término la lata misión encomendada a España en Marruecos ${ }^{59}$.

De todos modos, desde los primeros pasos masónicos, algunos musulmanes se interesaron y se iniciaron en la masonería, como se ha mencionado a propósito de la configuración del Gran Oriente de Marruecos. Una de las primeras logias configuradas en Tánger en manos españolas, Luz de Marruecos, no solo indicaba el deseo de propagar la luz, la modernidad y la civili-

56 Ojea Mata, 2015.

57 Odo, 2001: 90.

58 "La visita de Martínez Barrios a los talleres de Marruecos", Boletín del Gran Oriente Español, II/ 15 (Madrid, 10 de diciembre de 1927): 5-15.

59 Carta de Ramiro Farpón Pumariega a Cabo Espartel $n^{\circ} 447$ (Alcazarquivir, agosto de 1933), CDMH, SE Masonería A, legajo 115 exp. 11. 
zación por el territorio, sino que también estaría conformada por una mayoría de judíos y musulmanes en ese orden ${ }^{60}$. Sin embargo, nuestros resultados cuantitativos para fechas anteriores a la Segunda República indican que, a pesar de la retórica conciliadora, apenas se iniciaron musulmanes en el Arte Real. Pero, independientemente de ello, la proyección masónica giraba en torno a la integración de marroquíes "aptos" desde los preceptos de la modernidad occidental ${ }^{61}$, así como a la preparación, reeducación o, si se prefiere, civilización, de la población protegida de la colonia. Los propios nominativos que utilizan ya son un fiel reflejo de esta concepción.

Es representativo, en este caso, cómo las logias de la zona española denunciaron la actuación de los talleres de la zona francesa donde se negaban a iniciar musulmanes ${ }^{62}$. Por ejemplo, el Gran Orador, Hossain Ben Mohamed Hehe condena este hecho por antimasónico y por exhibir la diferencia de la actuación imperialista y colonial del Estado francés en relación con el español63. La política hispana, desde esta perspectiva, era aplaudida por los marroquíes precisamente por su carácter integrador y por su laxitud en general, aunque las iniciaciones fuesen menores debido a las altas tasas de analfabetismo - vinculadas a las medidas educativas hasta el momento insuficientes-, al imaginario colonial que los describía como "indígenas" y a los estereotipos asociados a la religión islámica y al creciente nacionalismo marroquí, ambos percibidos como fanatismo ${ }^{64}$. Es más, el nacionalismo de la colonia, al igual que sucedió con la masonería cubana, fue duramente criticado y discutido en estas logias, sobre todo porque algunos de sus representantes más importantes eran también conocidos masones. Así la Gran Logia de Marruecos en 1933 emitiría un decreto que consideraba este nacionalismo incompatible con la masonería ${ }^{65}$. Una vez más, el sentido patriótico y del deber en relación con España y su misión colonialista ganaba la partida en el seno de todos los talleres bajo su jurisdicción.

Sin embargo, estos no fueron los únicos problemas que tuvieron que afrontar las logias hispano-marroquíes: las persecuciones emprendidas hacia sus miembros, fuesen del grupo etno-cultural y etno-religioso que fuesen, estaban

${ }^{60} \mathrm{CDMH}, \mathrm{SE}$ Masonería A, legajo 605 exp. 8.

61 Aguiar Bobet, 2017a.

62 También propone acabar con tal prohibición. Libro de actas de la Gran Logia de Marruecos de 1 de mayo de 1933. Aguiar Bobet, 2017-2018: 70-91.

63 Aunque al principio de la colonización masónica francesa sí se iniciaba a musulmanes. Odo, 2001: 59.

64 Aguiar Bobet, 2017a; Aguiar Bobet, 2017-2018.

65 Libro de Actas de la Gran Logia de Marruecos, 4 de julio de 1933, CDMH, SE Masonería A, legajo 499. 
a la orden del día a pesar de estar legalizada la masonería durante el periodo republicano. $\mathrm{Y}$ este proceso represivo culminaría con su desestructuración desde 1934 hasta la guerra civil que daría el remate final.

Con todo, antes de abordar las legitimaciones concretas de los discursos de la masonería española en Cuba y Marruecos debemos remarcar una última cuestión. La atención ofrecida a cada una de estas colonias por parte de la masonería peninsular, sobre todo por las obediencias mencionadas, fue dispar. Es decir, la intención de controlar la masonería cubana y el interés otorgado a ella siempre fue mayor que en el Norte de África. Son numerosos los documentos que hacen relación a esta tal vez indiferencia ${ }^{66}$ hacia el territorio magrebí, que propiciaría, entre otras cosas, las numerosas persecuciones a las que se vieron sometidos por parte de los sectores más monarquizantes y fascistas de la colonia, muchos de los cuales ocupaban altos cargos civiles ${ }^{67}$. Esto también sucedía en la política republicana del protectorado en general. Su mantenimiento parece ser obligatorio en cuanto al deber español de civilizar el territorio y así evitar, entre otras cosas, que estuviese en manos francesas, con todo lo que ello podía implicar para el juego geopolítico europeo, sobre todo, de Inglaterra. Marruecos nunca sería Cuba ni tendría el mismo valor ni significado para los españoles. Y esto implicaría, al final, que los masones hispano-marroquíes debían construir y desarrollar un discurso y una actuación consecuente, paralelos al de la masonería metropolitana. Al final, en términos cuantitativos, sin presentar las altas cifras cubanas, se contabilizaron 60 talleres simbólicos y filosóficos a lo largo de su historia (1873-1936).

\section{HACIA UN "IDEAL MASÓNICO COLONIAL”}

En el anterior bosquejo formulado sobre la trayectoria masónica española en Cuba y en Marruecos hemos establecido algunas de las particularidades y analogías más representativas de su configuración y desarrollo, sobre todo en aquellos ítems relacionados directamente con el discurso colonialista proyec-

${ }^{66}$ En bastantes documentos los masones norteafricanos indican este desinterés y falta de apoyo por parte de sus obediencias respectivas, así como de la política republicana. De sobra conocida es, además, la política de este régimen en el territorio, que más que suponer un cambio, fue una continuación respecto a la situación de la dictadura primorriverista.

67 Los masones hispano-marroquíes avisaron en numerosas ocasiones (incluso desde el principio del periodo republicano) a sus respectivas obediencias peninsulares de la grave situación africana respecto al Alto Comisario Luciano López Ferrer en 1931. Paz, 2006a: 349-373. 
tado en cada una de ellas. El término colonialista utilizado aquí hace referencia a la especificidad de ser partidario del colonialismo ${ }^{68}$, como pasó en los dos casos mencionados. En este sentido ¿fue la masonería un vehículo más de la colonización española o bien es una institución colonizadora per se? ¿Cuáles fueron los motivos o cuál fue la finalidad de la colonización masónica en cada caso? Ya hemos dilucidado algunas de las variables que conformaron los discursos de la ocupación, expansión y consolidación de la masonería y, en otros artículos, hemos especificado el proyecto cosmopolitizador establecido en el Norte de África ${ }^{69}$. No obstante, debemos remarcar y valorar dichas variables en su justa medida, pues son las que determinaron, en última instancia, la configuración de un "ideal colonial masónico" para el territorio marroquí, sobre todo, en su último, pero más activo periodo, la Segunda República.

En el caso de Cuba, como vemos, tardío, donde ya existía una masonería anterior, francesa, norteamericana y propiamente criolla, se pretendía unificar la masonería prehispana con la española, de tal forma que no existiese una obediencia separatista o independiente de la metrópoli por los peligros pro-emancipadores que esto pudiese ocasionar. La causa que defendían era «además de masónica, nacional». Nacionalismo que abarcaba «la tierra española, peninsular, americana o filipina» ${ }^{70}$, dirá el mismo Gran Maestre Morayta para quienes el lema principal de los masones regulares era «Masonería, y el que sigue, Patria». Se puede decir, pues, que la masonería española en general propugnaba un ideal patriótico de unidad nacional ${ }^{71}$.

De hecho, la empresa bélica en Cuba a favor de su independencia fue considerada por todas las obediencias peninsulares como un gran dogma masónico definido por la defensa de la integridad del territorio nacional y, por tanto, justificaba la intervención militar. Tal y como más arriba indicábamos, el Boletín de Procedimientos de 27 de abril de 1898 dejaba claro que, si bien eran «masones enemigos decididos de la guerra», antes que nada, eran "españoles" y, como tales, «amantes entusiastas de nuestra querida patria, aceptamos y proclamamos la guerra con todas sus funestas y fatales consecuencias» ${ }^{72}$. Y así fue. La actitud de la masonería de obedien-

68 "Colonialista", Diccionario de la Real Academia Española (DRAE), última modificación 18 de septiembre, 2017.

69 Aguiar Bobet, 2017b.

70 Boletín de Procedimientos. Órgano oficial del Soberano Consejo General Ibérico, X/ 4 (Madrid, 27 de abril de 1898): 1-2.

71 Paz, 2006a: 737-760.

72 Boletín Oficial del Gran Oriente de España 50 (Madrid, 15 de mayo de 1892). 
cia peninsular en Cuba se estableció y desarrolló en medio del conflicto colonial, por lo que estuvo prácticamente definida desde los primeros momentos de su implantación. Es más, algunas de las logias, por ejemplo las de Ramón Bru en la década de los setenta, se establecieron con el encubierto objetivo de contrarrestar la supuesta labor y el apoyo que las logias cubanas estaban ofreciendo al movimiento conspirador e independentista ${ }^{73}$. Las obediencias hispanas eran contrarias al segregacionismo, aunque favorables a ciertas reformas políticas. Eran, ante todo, colonialistas, con todo lo que este término podía significar para España y para la orden: su grandeza, su hegemonía colonial, su situación geopolítica europea y, al fin y al cabo, su identidad como nación.

Además, la situación se complicaría tras el grave problema surgido en agosto de 1896 a raíz del descubrimiento en Filipinas de una organización secreta de carácter independentista compuesta por algunos miembros pertenecientes a la masonería y que poseía ramificaciones en el suelo peninsular ${ }^{74}$. La institución se convertía así en el centro de todas las sospechas y sería acusada de fomentar la insurrección independentista. La carga antimasónica que surgiría de estas acusaciones sería ya imparable para el resto de la trayectoria histórica colonial de España, hecho que se traduciría en ciertas actuaciones en Marruecos, aunque con tintes diferentes. Como antes mencionamos, Marruecos no era Cuba.

Entonces, ¿cómo se definieron y justificaron los objetivos de la instauración de la masonería en Marruecos después de los conflictos señalados en sus anteriores colonias de Ultramar? ¿Qué significaba Marruecos para la masonería española en este contexto nacional e internacional? ¿Cómo a partir de la situación colonial cubana y las otras precedentes los masones españoles construyen un posible "ideal masónico colonial"? Son numerosos los textos que disponemos, incluidos los estatutos y reglamentos generales de las logias y de las obediencias regionales, que impregnan el mismo discurso en torno a la "alta misión de la masonería española" en el Norte de África, a su deber de "civilizar" a los protegidos, es decir a los musulmanes y judíos, la mayoría de la población en este territorio. No obstante, la disertación proclamada por el delegado de la Comisión Permanente del Gran Oriente Español, Diego Martínez Barrio, en octubre $1927^{75}$ con motivo de su visita a los talleres de Marruecos, es muy clarificadora a este respecto.

73 Castellano Gil, 1996: 284.

74 Sánchez Ferré, 1987, tomo II: 481-496.

75 "La visita de Martínez Barrio a los talleres de Marruecos", Boletín del Gran Oriente Español, II/15 (Madrid, 10 de diciembre de 1927): 5-15. 
Colonizar es, si se procede rectamente, civilizar. Civilizar significa función tuitiva de hermanos mayores cerca de hermanos menores [...] Los pueblos musulmanes que constituyen Marruecos son actualmente pueblos degradados, si se quiere envilecidos [...] Nuestros Talleres tienen que convertirse en laboratorios donde se amalgamen los diferentes postulados de tales pueblos en crisis, para producir un nuevo tipo de civilización marroquí, que iguale o supere a aquel otro de tiempos pretéritos en el que fundan, hoy mismo, su orgullo y su ilusión.

En primer lugar, la narrativa de Martínez Barrio legitima la actuación que debe desarrollar la masonería española en Marruecos por medio de la "misión civilizadora", propia del canon colonialista europeo, que procede del propio discurso de la modernidad, en el que el modelo de nación, de hombre, de sistema y de comprender el mundo era exclusivamente el europeo, esto es, la noción del progreso, de la razón y la civilización en mayúsculas. Sin embargo, en segundo lugar, su narrativa responde a un canon colonial más específico que ha sido denominado, africanista, propiamente español, y que deriva tanto de la presencia militar española en el Norte de África durante el siglo XIX como del redescubrimiento y las nuevas perspectivas ideológicas e identitarias de España a propósito de su pasado andalusí. ${ }^{76}$ Esta narrativa ha sido definida por algunos autores como retórica de la hermandad ${ }^{77}$ pues se defendía el derecho legítimo, incluso moral de España a ocupar Marruecos a partir del pasado que compartían y no desde la superioridad racial de los españoles, a diferencia del canon colonial general europeo impuesto por las diferentes metrópolis en sus respectivas colonias. Y esa especificidad justificaba y legitimaba la intervención colonialista española puesto que no sería desde un rol superior autoimpuesto, sino desde una condición de "protección" al "hermano menor" en su inmadurez, o más bien, la "guía práctica" que se otorga al hijo pródigo según la parábola del Nuevo Testamento. Y en este sentido, entra la tercera variable de la configuración del discurso masónico español: en esta resignificación del pasado andalusí, en esta nueva concepción del "otro" que ya no solo es un "indígena", sino es un "hermano menor", las logias construyeron su propio imaginario: un nuevo Al-Ándalus masónico en el que Marruecos, por su propia condición colonial y multiétnica, se recreaba como el paraíso ficticio donde proyectar todos y cada uno de los preceptos masónicos. Es decir, el "ideal" producto de estos imaginarios culturales se basó en la construcción de una sociedad fraternal e igualitaria donde convivirían diferentes culturas y creencias religiosas sin exclusión o diferenciación y donde, además, los postulados universalistas y humanistas de la orden podían confi-

\footnotetext{
76 Martín-Márquez, 2011: 41-49.

77 Mateo Dieste, 2012.
} 
gurarse y trabajarse desde cero. Marruecos era un "diamante en bruto" desde el punto de vista colonialista y cosmopolitizador ${ }^{78}$ de la masonería.

No obstante, no podríamos hablar de un "ideal masónico colonial" si este discurso se hubiese construido de forma espontánea. Al contrario, para que exista la idealización se requiere de una experiencia anterior, y que esta haya sido necesariamente insatisfactoria. Y esta es la última variable que entra en juego en la construcción de una nueva "civilización marroquí", según los términos empleados por Martínez Barrio más arriba. Para discernir tal fin, se mostrarán dos textos representativos desde donde partió nuestra conceptualización. Ambos fueron publicados en la revista masónica Destellos de la logia Perseverancia no. 70 de Larache, con motivo de la festividad de la raza y la hispanidad el 12 de octubre de 1933. El primero de ellos nos dice:

Y a esa obra de aproximación hispano americana, unida a la que España realiza en África junto al pueblo marroquí, pueblo este que también lleva nuestra sangre, será sin duda la obra que más libre del remordimiento de culpas pasadas, hijas de la intolerancia religiosa de hace cinco siglos y que perdurando hasta hace poco, pretenden algunos mantener aún. El día que España se una de manera efectiva, sin reservas mentales, a los pueblos de la América hispana y al pueblo marroquí, será la apoteosis del Gran Día de la Fiesta de la Raza ${ }^{79}$.

Como vemos, por un lado, se interrelaciona la conquista de América con la labor desarrollada en África en un intento de legitimar las relaciones históricas y la colonización de ambas desde una visión paternalista del modelo colonial impulsado por el estado. Y, por otro, se condena la intolerancia religiosa con la que se llevó a cabo la conquista, hecho que se pretendía disminuir y frenar en Marruecos: ambos "pueblos" llevaban sangre hispana y compartían un pasado histórico común. Y esto dotaría de orgullo y altruismo a los masones que trabajaban en pro del ideal. España - y la orden con ella- se redimiría y se alzaría con más fuerza al crear y configurar la sociedad idílica que marcaban sus preceptos.

En el otro texto, también con motivo del día de la raza, se indica:

...aztecas, Incas, de omnímodo poder; [...] todos cayeron arroyados, más que por la fuerza numérica de los invasores, más que por la bravura que les daba fama y el arrojo sin límites que derrochaban; por la fuerza convincente, augusta, de las leyes sabias que implantaron, inspiradas en austeros principios de justicia. Ellas pretendieron en aquel pueblo el amor a la igualdad, engendrando el ansia de eman-

78 Aguiar Bobet, $2017 \mathrm{~b}$.

79 "Solo la Fraternidad une a los Hombres y a los Pueblos", Destellos (Larache, 12 de octubre de 1933): 1 . 
cipación que les condujo a la libertad. De esto nada menos, fueron portadores aquellos aventureros, que cincelaron a golpes de heroísmo, el pasaje más brillante en la historia de una raza ${ }^{80}$.

Esta alusión ensalzadora de la independencia de las antiguas colonias especialmente la de Cuba que 30 años antes denostaban-, puede parecer contradictoria, pero no lo es: aquí no se habla de la espada de la conquista, ni de la religión impuesta, aquí se habla de las leyes, se habla de la superioridad cultural que dio luz, que mejoró las culturas precolombinas, que las hizo crecer y hasta querer emanciparse, porque fue España quien le ofreció esa oportunidad de civilizarse, lo mismo que pretendían con la ejecución de su ideal colonial en Marruecos. La lucha anticlerical y antibélica en las logias del protectorado fue muy fuerte en este sentido. Tanto el peso de las misiones católicas como el de las "guerras de pacificación" habían sido bastante significativos desde la ocupación española. Por ello la dominación pretendida, a través del pasado común y de la retórica africanista, era cultural, es decir, ni religiosa ni militar. Civilizar la barbarie y otorgarle a España su papel de Madre Patria, su prestigio nacional e internacional perdido, eran las máximas que subyacían detrás de la narrativa construida.

Sin embargo, este discurso tiene también su contextualización histórica. A raíz de la pérdida de Cuba, Puerto Rico y Filipinas, algunos sectores republicanos creyeron que al fin había llegado su hora y que, a partir de entonces, España podría reencauzar un destino de regeneración y progreso a favor de la democracia, de la reconstrucción nacional y de las libertades públicas, pues les parecía increíble que, tras las pérdidas territoriales que se acababan de experimentar y de las que culpaban a los políticos de la Restauración, el país no estuviese en condiciones inmejorables para cambiar el rumbo de su historia. El desastre del 98, como muchos le llamaron, dejó una huella profunda, sobre todo en un conjunto de militares y políticos que concibieron la aventura colonial norteafricana como la última esperanza imperial de España, y que habían vivido, directa o indirectamente, la derrota frente al poder avasallador de los Estados Unidos. De esta época arranca esa extraña mezcla de rencor y temor con la que el poder central ha observado, desde entonces, todos los nacionalismos no estrictamente españolistas, como sucederá también con el nacionalismo marroquí al que las logias norteafricanas terminan por identificar con el fascismo.

Pero, además, ya desde finales del siglo XVIII y comienzos del XIX, se empezarían a cuestionar los denuedos anteriores por construir España como

\footnotetext{
80 Idem.
} 
una uniforme entidad católica de etnia y raza puras y se excavarían los rastros de densas capas que dejaron tras sí los nueve siglos de coexistencia entre cristianos, musulmanes y judíos. Comienza aquí lo que denomina Susan Martín-Márquez, «la segunda oleada de construcción nacional» ${ }^{81}$ con importantes sectores de la población promocionando una visión iconoclasta del pasado colonial. Coincidiendo con la pérdida de las colonias en América, esta era de reconstrucción nacional también estaría acompañada del gesto compensador de la segunda oleada de colonización, cuando los africanistas españoles comenzaron a abogar por la búsqueda de un nuevo futuro imperial en el viejo continente. Era una asociación entre la recuperación histórica de España de la herencia africana y americana y sus aspiraciones coloniales en África. Los políticos intelectuales, escritores españoles y los masones instalados en el Norte de África, intentaron, por tanto, valorar y movilizar su herencia andalusí a fin de alcanzar un lugar privilegiado dentro de la comunidad europea de la época.

De este modo, el concepto de hispanidad hábilmente omitía la cuestión de raza biológica al tiempo que exaltaba los profundos lazos familiares y pretéritos que unían a todos los habitantes de las colonias de ultramar y africanas con la metrópoli 82 ; sobre todo teniendo en cuenta que las percepciones del resto de países sobre España no eran tan favorables ni propicias como hubiese gustado a los españoles ${ }^{83}$. Incluso Joaquín Costa señalaba que a raíz de Cuba España no estaba capacitada para su lugar en Europa ${ }^{84}$, es decir, para civilizar a otros territorios. Será entonces cuando la masonería española en Marruecos proyecte su discurso colonialista, un "ideal masónico colonial" perfectamente estructurado y coherente. Un imaginario en el que convergían los preceptos masónicos presentes desde las constituciones de Anderson (1723) dos siglos atrás ${ }^{85}$ - que recobraba un nuevo significado en esta utopía filantrópica- y donde, además, Marruecos se percibía como un diamante en bruto en el que poder configurar, esta vez de verdad, tales preceptos. Era un territorio virgen, salvaje, en el que también se redimirían de los actos realizados en los procesos coloniales americanos anteriores. Por tanto, se trataba de una reconciliación colonial americano-marroquí, una redención de la ac-

\footnotetext{
81 Martín-Márquez, 2011: 33-41.

82 Ibidem: 49-61.

83 Muchos intelectuales como Víctor Hugo, Delacroix dejaron constancia de que España, a sus ojos, seguía siendo "Oriente" o bien "medio africana", Martín-Márquez,

84 Idem.

85 Mollès, 2015: 197-209.
} 2011: 41-49. 
tuación española en América. No es de extrañar que justo el 12 de octubre de 1912, a un mes de formalizar e institucionalizar el protectorado de Marruecos, se estableciera el Día de la Raza, del descubrimiento de América y de la Virgen del Pilar, patrona de España. Ni tampoco que las logias norteafricanas rememorasen en diversas ocasiones este tan significativo acontecimiento tal y como vimos con la revista Destellos de Larache. Lo que no quiere decir, pese a ello, que al final, el propio ideal y el propio proyecto se viesen truncados por los propios límites conceptuales y contextuales del canon colonial africanista. Y el mayor ejemplo de ello fue, en la praxis, la escasa iniciación de musulmanes y la escisión producida entre el nacionalismo marroquí y la masonería patria ${ }^{86}$. Al final, tampoco para la masonería hispana seguiría siendo factible aprobar y aceptar un Marruecos no español.

\section{EPÍLOGO: ENTRE LO IMAGINARIO Y LO IDEAL EN EL DISCURSO MASÓNICO}

El "ideal masónico colonial" que configuraron las logias norteafricanas fue un discurso construido por y desde el imaginario cultural español y, a la vez, desde un imaginario masónico preexistente en y consustancial $a$ los preceptos y estamentos de la orden. Fue un producto narrativo que subyacía de la modernidad en la que se estableció y desarrolló la masonería en sus primeros pasos "especulativos", y de la actuación de la orden española - y de España en sí- en sus ex-colonias americanas, principalmente en Cuba. Sin embargo, para poder interpretar en su total complejidad la necesidad de conformación de este ideal, hemos partido, por un lado, de la concepción foucaultiana de "construcción de discursos", entendiendo esta construcción con su propia dinámica interna y con sus propios procedimientos y principios de clasificación, exclusión y desfases ${ }^{87} \mathrm{y}$, por otro, de la sociología del imaginario de la tradición francesa, concretamente a partir de la propuesta iniciada en los 60 por Gilbert Dürand ${ }^{88}$. La noción del imaginario debe comprenderse como representación de la realidad social, como la hermenéutica del componente mítico-simbólico, propiamente ideacional, que está implicado e irriga de sig-

\footnotetext{
86 Aguiar Bobet, 2017-2018.

87 Así lo establece Michel Foucault en su clásica conferencia de ingreso al Collège de France en 1970. Citado en Pizarro, 2013: 83-86.

88 G. Dürand descubre una función eufemizadora en la imaginación de la que emana un dinamismo creativo, a través del cual el hombre busca compensar las carencias y desajustes provocados por el excesivo proceso de secularización de la modernidad, lo que terminará por desencadenar una reificación cultural. En este sentido, lo imaginario es constituyente esencial de lo real. Dürand, 1982.
} 
nificación a diferentes contextos de la vida cotidiana y de la experiencia social. De hecho, el objetivo central de su estudio es mostrar que, a pesar de los pesimistas augurios de la modernidad, lo religioso y lo mítico, lejos de desaparecer del campo social, se transmutan bajo nuevas materializaciones históricas $^{89}$ en las que cabe destacar las ideologías políticas, el culto litúrgico patriótico o todo el conjunto discursivo de la parafernalia masónica. Es significativo, a este respecto, un texto publicado en el Boletín del Gran Oriente Español en 1926 sobre la diferencia entre la masonería francesa y española en sus colonias a propósito del papel que debiera seguir la orden:

La administración francesa no pone trabas al desarrollo de la Masonería en las colonias, ni dentro de aquellos territorios europeos, africanos o americanos donde conviven varias masonerías regulares, convencida, como lo está de que la Orden Masónica es un instrumento de cultura y progreso, que favorece con sus enseñanzas el triunfo de los principios de civilización. [...] Lo mismo franceses que ingleses han comprendido que no hay organización internacional que supere a la Francmasonería en la obra de armonizar las aspiraciones de los pueblos colocados en distintos momentos de la civilización, pues sus enseñanzas de fraternidad crean la zona neutral donde pueden encontrarse los adversarios políticos nacionales.

El texto continúa después de juzgar la actuación de la Iglesia en su misión siempre «excluyente y estrecha» que «tiende a sustituirse en la fe de los pueblos intervenidos» con las siguientes claves reveladoras del imaginario masónico:

La masonería, como no se considera depositaria de una verdad superior que deba imponer a los hombres, sino que aspira tan solo a crear o desarrollar en ellos el espíritu de fraternidad, es singularmente apta para las empresas políticas que tienen como finalidad primordial la de elevar espiritualmente a los pueblos degradados o infantiles. Por eso su inmensa utilidad social en las avanzadas que las naciones europeas sostienen en África, Asia y Oceanía. Por eso el afán de la administración francesa en facilitar la labor de las logias coloniales, más útiles para la pacificación del territorio que la acción unilateral y sectaria de cualquier Iglesia oficial ${ }^{90}$.

Al fin y al cabo, la crítica ofrecida y reprochada a la Iglesia en su superioridad religiosa-trascendental era la misma que la masonería imponía desde su superioridad cívico-moral. Y en ello se fundan todas y cada una de las legitimaciones y justificaciones de la acción masónica colonial y no colonial

89 Carretero Pasín, Tercera época/41 (Madrid, mayo-agosto, 2005): 145.

90 "Digno de estudio. Sobre la masonería francesa en África", Boletín del Gran Oriente Español I, 1 (Madrid, 10 de octubre de 1926): 4-6. También BGOE, II/5 (Madrid, 10 de febrero de 1927). 
en sus diferentes discursos construidos: a través del imaginario cultural español y masónico, el proyecto de la masonería en Marruecos se alza como un orden alternativo a la realidad socialmente instituida ${ }^{91}$. La modernidad que plaga el lenguaje masónico, al consagrar una racionalidad instrumental y productiva, incitaría precisamente a la creación de un imaginario propio, en este caso, a lo que debe ser la colonia, a lo que debe ser España y a lo que debe ser la institución masónica. Todo ello para legitimar una interpretación significativa que justifique un determinado orden y estructura social. Y el elemento fundamental que permitiría dar cuenta de ello es una originaria idée fondatrice $e^{92} \mathrm{de}$ protección que, a través de la experiencia anterior americana, sirviese de cemento social y posibilitase la dominación simbólica de Marruecos por parte de la masonería. De ahí que el ideal masónico remita necesariamente a un principio religioso: aquello que re-liga a unos individuos que comparten unos presupuestos comunes, aun cuando esta religiosidad se encarne en instancias tan dispares como La Patria, El Progreso, La Civilización, La Alta Misión Masónica, etcétera.

En último lugar, el otro fundamento que compondría la construcción discursiva del ideal marroquí, siguiendo el marco teórico mencionado, es el de la utopía, cuya intención versaría en compensar las carencias y miserias de la realidad presente. Las elaboraciones utópicas en sus diferentes expresiones históricas, proponen una felicidad terrestre, un encantado futuro en el que se condensa el ansia de la imaginación por trascender lo real ${ }^{93}$. Su naturaleza descansa en la propuesta de un mundo mejor y más hermoso, como la imagen perfecta, nunca realizada históricamente, que proyecta un futuro modélico donde trascienden la miseria, la crueldad, la dureza y la trivialidad del mundo que, como hemos visto, representaría la realidad de Marruecos a ojos de los masones españoles.

Sintetizando, la hermenéutica propia de la sociología del imaginario de tradición francesa y la asunción foucaultiana de los discursos, nos han proporcionado ciertas claves pertinentes sobre la construcción narrativa del "ideal masónico colonial" a partir de las experiencias y retóricas colonialistas aquí tratadas. En este caso, hemos visto que se fundamentan en varios imaginarios culturales que convergen en uno solo: la identidad española y de España como nación, los errores y abusos de la primera situación colonial (incluidos los masónicos) y el destino cuasi-divino de la masonería española para redimir, regenerar y reconciliar los errores de la nación. Pero todo ello con el deseo de crear

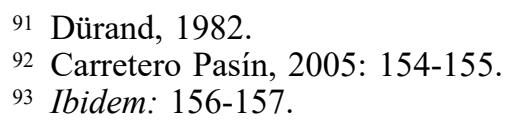


o configurar una sociedad pura - y utópica - desde sus preceptos. Una sociedad ejemplar, ideal para el resto del territorio nacional y para toda la humanidad. Un imaginario, al fin y al cabo, construido implícitamente para legitimar y justificar, más que el poder colonialista de la masonería en África, su promulgación como la institución más capaz de influenciar, cambiar y mejorar el destino político-social de España y, con ello, la identidad de la propia nación.

En todo caso y para terminar, esta primera aproximación a la interpretación de los imaginarios masónicos, coloniales, españoles, etcétera, requiere de más estudios, analogías y confrontaciones que permitan extralimitar su fuerza discursiva, tanto social como culturalmente. Lo que nos llevaría, en futuros trabajos, a repensar la imbricación de los imaginarios en una doble vertiente: por una parte, recalcando su trascendencia en las formas de legitimación de la actuación colonial y sociocultural en cada territorio donde se implantaron, desarrollaron y transmutaron y, por otra parte, descubriendo en lo imaginario una fuente de contrapoder, de insubordinación ante una ciega credibilidad en una única posible realidad admitida sin cuestionamiento en torno a su papel en la sociedad y el destino de la nación, de la colonia y, si se quiere, de la humanidad.

\section{BiBLIOGRAFÍA}

Aguiar Bobet, Valeria, En busca de un nuevo al-Ándalus. El legado documental de la masonería hispano-marroqui, Santa Cruz de Tenerife: Ediciones Idea, 2019a.

Aguiar Bobet, Valeria, "Ni complot judeo-masónico ni filosemitismo: la ambivalencia discursiva, la ambivalencia discursiva del encuentro cultural hispano-judío en las logias norteafricanas", Hispania, 79/261 (Madrid, 2019b): 189-219.

Aguiar Bobet, Valeria, "La cultura de la tolerancia en el Marruecos de la II República: el VIII Centenario de Maimónides”, Miguel Delgado e Yván Pozuelo (coord.), La masonería hispano-lusa y americana, De los Absolutismos a las Democracias (1815-2015), Zaragoza, CEHME, 2017a: 493-507.

Aguiar Bobet, Valeria, "La masonería española en el protectorado marroquí: un proyecto colonial y cosmopolitizador", Ricardo Martínez, Yván Pozuelo y Rogelio Aragón (eds.), 300 años: masones y masonería (1717-2017). Tomo V Cosmopolitismos, México, Palabra de Clío, 2017b: 144-168.

Aguiar Bobet, Valeria, "Hermano moro: masonería y colonialismo en el Protectorado español de Marruecos (1931-1936)", Revista de Estudios Históricos de la Masonería Latinoamericana y Caribeña, 9/2 (Puntarenas, 2017-2018): 56-92. https:// doi.org/10.15517/rehmlac.v9i2.31167 
Byrne, Birne, "Apuntes sobre la Historia de la Masonería cubana", Ediciones de la Gran Logia de la Isla de Cuba, La Habana, Imprenta El Siglo XX, 1913.

Carretero Pasín, A. Enrique, "Imaginario y sociedad. Un acercamiento a la sociología de lo imaginario en la tradición francesa", Revista Internacional de Sociología (RIS), Tercera época/41 (Chile, 2005): 137-161.

Castellano Gil, José Manuel, La masonería española en Cuba, Santa Cruz de Tenerife, Centro de Cultura Popular Canaria, 1996.

Dürand, Gilbert, Las estructuras antropológicas de lo imaginario, Madrid, Taurus, 1982.

Ferrer Benimeli, José Antonio, "Preocupación de la masonería en Tánger por la educación y la paz en Marruecos (1906-1920)", Cuadernos de Historia Contemporánea, 14 (Madrid, 1992): 75-90.

Ferrer Benimeli, José Antonio, "La masonería española y la crisis colonial del 98", Francisco Morales Padrón (coord.), XIII Coloquio de Historia Canario-America$n a$, Las Palmas de Gran Canaria, Ediciones del Cabildo de Gran Canaria, 2000: 159-180.

Hernández González, Manuel, Liberalismo, masonería y cuestión nacional en Cuba 1808-1823, Santa Cruz de Tenerife, Idea, 2012.

López García, Bernabé, "Los españoles en Tánger”, AWRAQ: Estudios sobre el mundo árabe e islámico contemporáneo, 5-6, (Madrid, 2012): 1-46.

Martín Corrales. Eloy, Marruecos y el colonialismo español (1859-1912). De la guerra de África a la "penetración pacífica", Barcelona, Bellaterra, 2002b.

Martín-Márquez, Susan, Desorientaciones. El colonialismo español en África y la performance de la identidad, Barcelona, Ediciones Bellaterra, 2011.

Martínez Antonio, Francisco Javier, "Dos dedos de una misma mano: propuestas para un nuevo análisis de las relaciones entre España y Marruecos a finales del siglo XIX”, Francisco Javier Martínez Antonio e Irene González González (coords.), Regenerar España y Marruecos. Ciencia y Educación en las relaciones hispano-marroquies a finales del siglo XIX, Madrid, CSIC, 2011: 19-61.

Mateo Dieste, Josep Lluis, "Una hermandad en tensión. Ideología colonial, barreras e intersecciones hispano-marroquíes en el Protectorado", $A W R A Q, 5-6$, (Madrid, 2012): 79-96.

Moga Romero, Vicente, "La aproximación de la masonería en Ceuta en el siglo XIX”, José A. Ferrer Benimeli (coord.), La masonería en España en el siglo $X I X$, Salamanca, Junta de Castilla y León, Consejería de educación y Cultura, 1987: 297-309.

Moga Romero, Vicente, Al oriente de áfrica. Masonería, Guerra Civil y represión en Melilla (1894-1936), Melilla, UNED-Centro Asociado de Melilla, 2005. 
Moga Romero, Vicente y Perpén Rueda, Adoración, “Orígenes ideológicos de los talleres masónicos contemporáneos en Melilla: Militares y Masonería (19831927)”, José A. Ferrer Benimeli (coord.), Masonería, revolución y reacción, Alicante, Diputación Provincial de Alicante, Instituto Alicantino de Cultura Juan Gil-Albert, 1990, vol. II: 717-741.

Mollès, Dévrig, "Esta religión sobre la cual todos los hombres concuerdan: la invención de la masonería, una revolución cultural entre religión, ciencia y exilios", Revista Brasileira de História das Religiões (ANPUH), VIII/23 (Maringá, 2015): 177-211. https://doi.org/10.4025/rbhranpuh.v8i23.28874

Odo, Georges, La franc-maçonnerie dans les colonies, 1738-1960, París, Éditions Maçonniques de France, 2001.

Ojeda Mata, Maite, "La ciudadanía española y los sefardíes: identidades legitimadoras, ideologías étnicas y derechos políticos”, Quaderns-e 20/2 (Barcelona, 2015): 35-52.

Paz Sánchez, Manuel de, “Aspectos generales y principales características de la implantación sistemática de la francmasonería en la Gran Antilla, durante la segunda mitad del siglo XIX", Anuario de Estudios Americanos, XXXVI (Sevilla, 1979): 534.

Paz Sánchez, Manuel de, La masonería y la pérdida de las colonias, Santa Cruz De Tenerife, Idea, 2006a.

Paz Sánchez, Manuel de, "Masonería española y emancipación colonial", Revista de Indias, LXVI/ 238 (Madrid, 2006b): 737-760. https://doi.org/10.3989/revindias.2006. i2 238.338

Paz Sánchez, Manuel de, "España, Cuba y Marruecos: masonería, identidades y construcción nacional", Anuario de Estudio Atlánticos, 55 (Las Palmas de Gran Canaria, 2009): 273-310.

Pizarro, Ana, "Colonialidad: observaciones sobre la construcción de discursos", $T a-$ ller de Letras, 53 (Santiago de Chile, 2013): 83-97.

Sá, Ana Lucia, "La construcción de la imagen del indígena en las poblaciones españolas del Golfo de Guinea (1904-1912)", Yolanda Aixelá Cabré (ed.), Tras las huellas del colonialismo español, Madrid, CSIC, 2015: 89-112.

Sampedro Ramos, Vicent, Julio Cervera Baviera, republicano y masón, Castellón de la Plana, Universitat Jaume I, 2015.

Sánchez Ferré, Pedro, "Masonería y colonialismo español”, José A. Ferrer Benimeli (coord.), La masonería y su impacto internacional, Madrid, Universidad Complutense de Madrid, El Escorial, 1989: 19-20.

Sánchez Ferré, Pedro, "La masonería española y el conflicto colonial filipino", José A. Ferrer Benimeli (coord.), La masonería en España en el siglo XIX, tomo II, Valladolid, Junta de Castilla y León, Consejería de educación y Cultura, 1987: 481-496. 
Saunier, Éric, "Les pratiques culturelles dans un port de traite. Les négriers et la franc-maçonnerie au Havre au XVIIIe siècle", M. Dorigny (coord.), Esclavage, résistances et abolitions, Paris, Editions du CTHS, 1999: 139-151.

Saunier, Éric, "El espacio caribeño: un reto de poder para la masonería caribeña", Ricardo Martínez, Yván Pozuelo y Rogelio Aragón (eds.), 300 años: masonerías y masones. Tomo I: Migraciones (1717-2017), México, Palabra de Clío, 2017: 76-90.

Soucy, Dominique, Masonería y nación (1811-1902). Redes masónicas y políticas en la construcción identitaria cubana, Santa Cruz de Tenerife, Ediciones Idea, 2006.

Torres Cuevas, Eduardo, "Los complejos orígenes de la masonería en Cuba. El Templo de las Virtudes Teologales", Revista de Estudios Históricos de la Masonería Latinoamericana y Caribeña, Número especial UCLA - Gran Logia de California (Puntarenas, 2013): 105-115.

Torres Cuevas, Eduardo, "Masonerías en Cuba durante el siglo XIX", Ricardo Martínez, Yván Pozuelo y Rogelio Aragón (eds.), 300 años: masonerías y masones. Tomo I: Migraciones (1717-2017), México, Palabra de Clío, 2017: 46-75.

Fecha de recepción: 22 de mayo de 2018.

Fecha de envío de las modificaciones: 5 de septiembre de 2018.

Fecha de aceptación: 13 de diciembre de 2018.

\section{The Spanish masonry in Cuba and Morocco: ideals, imaginaries and colonial utopias}

In this article, we compare the role of Spanish Freemasonry in Cuba and Morocco from its colonial situation, emphasizing the variables that lie behind both of them: how the masonry legitimizes or justifies it action in the colonies, if it is established or not as one more element of colonization but, above all, if it ends up configuring an ideal colonial model that would derive in the discourse projected in the Spanish protectorate of Morocco. For this purpose, the sociology of the imaginary will provide us with the methodological basis for analyzing the Masonic discourse and the precepts that configure it, using, as a documentary basis, the sources produced by the Masonic instances, bulletins and newspapers, as well as the specialized bibliography on this subject.

KeY words: Spanish masonry; Cuba; Morocco; colonialism; sociology of the imaginary. 